\title{
PENGGUNAAN METODE KUBACA UNTUK MENINGKATKAN KEMAMPUAN MEMAHAMI KATA ANAK USIA DINI DI RAUDHATUL ATHFAL
}

\author{
Istianah $^{1}$, Mundir $^{2}$ \\ ${ }^{1}$ Prodi PIAUD IAIN Jember \\ e-mail: isti3588@gmail.com \\ ${ }^{2}$ Prodi PAI S3 IAIN Jember \\ e-mail: mundzirrosyadi@gmail.com
}

\begin{abstract}
The ability to read at an early age greatly affects the level of intelligence of children. The earlier a child learns to read, the more fond he is to read and the better he will read. So parents and teachers should teach children to read from an early age. Because the ability to read is the basis for mastering various sciences. The purpose of this study was to analyze and describe the steps of implementing the "Kubaca" method which can improve the ability to recognize the words of early childhood Raudhatul Athfal Perwanida 19 Bangsalsari Jember. This research uses a qualitative approach and types of field research. The data collection techniques used included observation, interviews, and documentation. This study concluded that the steps for implementing the Kubaca method that can improve the ability to recognize early childhood words in Raudhatul Athfal Perwanida 19 are as follows: 1) the teacher prepares various kinds or kinds the words to be conveyed to students, 2) the teacher holds up the words that have been arranged neatly, and 3) the teacher reads the cards aloud and repeatedly.
\end{abstract}

Keywords: reading methods, ability to recognize the words, early childhood

\section{ABSTRAK}

Kemampuan membaca pada usia dini banyak mempengaruhi tingkat intelegensi anak. Semakin dini seorang anak belajar membaca maka semakin gemar ia membaca dan semakin baik ia membaca. Maka seharusnya orang tua dan guru mengajarkan anak membaca sejak dini. Karena kemampuan membaca merupakan dasar untuk menguasai berbagai ilmu.Tujuan penelitian ini adalah menganalisis dan mendeskripsikan langkah-langkah penerapan metode "Kubaca" yang dapat meningkatan kemampuan mengenal kata anak usia dini Raudhatul Athfal Perwanida 19 Bangsalsari Jember.Penelitian ini menggunakan pendekatan kualitatif dan jenis penelitianlapangan. Teknik pengumpulan data yang digunakan meliputi observasi, wawancara,dan dokumentasi.Penelitian ini memperoleh kesimpulan bahwa langkahlangkah penerapan metode Kubaca yang dapat meningkatkan kemampuan mengenal kata anak usia dini di Raudhatul Athfal Perwanida 19 adalah sebagai berikut: 1) guru menyiapkan aneka ragam atau macam kata-kata yang akan disampaikan kepada siswa, 2) guru mengacungkan kata-kata yang telah disusun secara rapi, dan 3) guru membacakan kartu-kartu tersebut secara nyaring dan berulang-ulang.

Kata Kunci: metode membaca, kemampuan memahami kata, anak usia dini 


\section{PENDAHULUAN}

Pendidikan Anak Usia Dini (PAUD), merupakan suatu upaya pembinaan yang ditujukan kepada anak sejak lahir sampai dengan usia enam tahun yang dilakukan melalui pemberian rangsangan pendidikan untuk membantu pertumbuhan dan perkembangan jasmani dan rohani agar anak memiliki kesiapan dalam memasuki pendidikan lebih lanjut (Kemendikbud.2014:3).

Anak Usia Dini biasanya telah mampu mengembangkan keterampilan berbicara melalui percakapan yang dapat memikat orang lain. Mereka dapat menggunakan bahasa dengan berbagai cara serperti bertanya, berdialog, dan bernyanyi. Sejak Usia Dua tahun anak menunjukan minat untuk menyebut nama benda. Minat tersebut terus berkembang sejalan dengan bertambah usia dan menunjukkan bertambah pula perbendaharaan kata (Isjoni. 2017:2).

Mengajarkan anak membaca sebaiknya dilakukan sedini mungkin. perkembangan bahasa anak tergantung pada interkorelasi dari berbagai factor antara lain: intervensi awal, intervensi berbahasa dan pengalaman hidup anak terkait dengan kehilangan pendengarannya. Sejalan dengan membaca merupakan jantung pendidikan. Dalam hal ini, orang yang sering membaca, pendidikan akan maju dan ia akan memiliki wawasan yang luas. Dalam hal ini keterampilan membaca merupakan salah satu aspek dari keterampilan berbahasa (Dalman.2017:5).

Kemampuan membaca pada usia dini banyak mempengaruhi tingkat intelegensi anak. Semakin dini seorang anak belajar membaca maka semakin gemar ia membaca dan semakin baik ia membaca. Maka seharusnya orang tua dan guru mengajarkan anak membaca sejak dini. Kemampuan membaca merupakan dasar untuk menguasai berbagai ilmu. Jika pada usia sekolah permulaan tidak segera memiliki kemampuan membaca, maka ia akan mengalami kesulitan dalam mempelajari berbagai kegiatan belajar. Oleh karena itu, anak harus belajar membaca agar ia dapat membaca untuk belajar.(Dalman. 2017: 5). Begitu pentingnya arti membaca hingga Allah Swt Berfirman dalam Al-Qur'an Surat Al-Alaq ayat 1-5.

Anak usia dini berada dalam tahap pertumbuhan dan perkembangan yang paling pesat, baik fisik maupun mental. Maka tepatlah bila dikatakan bahwa usia dini adalah usia emas (golden age), di mana anak sangat berpotensi mempelajari banyak hal dengan cepat termasuk belajar membaca. juga mendukung pernyataan ini, karena menurutnya waktu terbaik untuk belajar membaca kira-kira bersamaan waktunya dengan anak belajar bicara, dan masa peka belajar anak terjadi pada rentang usia 3 hingga 5 tahun. Memperkenalkan dunia membaca kepada anak lebih awal, akan membantunya memiliki kemampuan untuk mengenali banyak hal dan memberinya pemahaman tentang sesuatu yang mereka baca. Setiap anak yang terbiasa membaca sejak dini, akan mempelajari cara berbahasa yang benar (Isjoni. 2017:11).

Dengan demikian, mereka memiliki peluang untuk bisa menjalin hubungan secara lebih luas dengan keadaan di sekelilingnya. Hal yang tidak kalah penting adalah kemampuan dasar yang 
dibentuk dengan cara membaca akan terus terbawa selamanya. Pada usia dini, anak yang tidak bisa mempertahankan ingatannya terhadap apa yang telah dipelajarinya merupakan sesuatu yang sangat wajar. Hal yang terpenting adalah sikap yang tidak mudah menyerah dan putus asa untuk tetap mengajarinya membaca. Maka dapat disimpulkan bahwa pengajaran membaca sejak usia Taman Kanak-kanak atau bahkan sejak usia 3 tahun bukanlah sesuatu yang aneh atau tidak boleh dilakukan, karena yang terpenting adalah pengemasan materi serta metode yang digunakan.

Saat ini terdapat metode baru untuk meningkatkan keterampilan membaca yaitu metode membaca cepat Kubaca yang diciptakan oleh Diah Lestari (2003:54). Setelah metode ini diujicobakan pada anak usia 3-4 tahun, metode kubaca mulai disebarluaskan di Indonesia sejak Juli 2005, dan telah terdaftar dengan Hak Cipta No. 031744 Tanggal 27-12-2005. Keunggulan metode Kubaca terletak pada sistem membaca kata secara utuh, dengan pilihan kata yang tepat (corpus linguistik) sesuai dengan perkembangan pemerolehan bahasa anak sebagai pembaca pemula. Jadi, metode Kubaca langsung mengajari anak membaca kata. Kemudian anak diajari menyusun kata menjadi kalimat yang baik dan benar, anak akan lebih mudah dan cepat dalam membaca. Hal ini sangat berbeda dengan pembelajaran membaca di sekolah pada umumnya yang mengajarkan huruf alfabet atau suku kata yang tidak bermakna (Rizka Rojiyatul Azizah dan Sulthoni. 2017: 146).

Metode kubaca dipijakkan pada konsep emergent literacy (kebutuhan yang harus dipenuhi) bukan reading readiness (hanya mempersiapkan anak membaca) yang lebih holistic dan sadar akan kemajemukan kecerdasan manusia, terutama pada masa pertumbuhan dan perkembangan anak. Metode pembelajaran kubaca juga mempunyai konsep belajar membaca berbasis kata bukan mengeja huruf. Dengan metode kubaca, pembaca pemula, terutama anak balita, akan belajar membaca melalui berbagai macam permainan yang menyenangkan dan dibantu dengan kartu-kartu kata. Bagi balita, metode kubaca akan menjadi lahan yang subur dan papan lontar (spring-board) bagi perkembangan kreatifitas mereka serta memberi mereka kemampuan menggagas sesuatu, baik secara lisan maupun tertulis (Rizka Rojiyatul Azizah dan Sulthoni. 2017: 146).

Hal yang menarik atau bisa juga dikatakan unik pada metode kubaca dalam meningkatkan kemampuan memahami kata di RA Perwanida 19 Bangsalsari ini adalah tenaga pendidik secara naluriah dan berkesinambungan melaksanakan metode kubaca ini terhadap peserta didik agar memudahkan peserta didik dalam menerima materi, terutama mengenai membaca. dengan adanya metode ini pula dapat membantu siswa untuk meningkatkan kemampuan memahami kata yang diinginkan sehingga meningkatkan daya ingat anak lebih berkembang dan termotivasi. Oleh karna itu pendidik merancang metode kubaca untuk memberikan materi yang diharapkan dapat menunjang dan membantu peserta didik agar mampu memahami kata dalam mencapai materi yang hendak dicapai tanpa harus menyinggung atau mematahkan semangat peserta didik dalam mencari pengetahuan, dan hal yang menarik juga untuk diteliti terkait masalah metode kubaca dalam meningkatkan kemampuan memahami kata. 
Hasil observasi di RA Perwanida 19 Bangsalsari siswa diajar membaca dengan metode Kubaca yang dilaksanakan pada setiap pelaksanaan kegiatan belajar mengajar dengan harapan agar nantinya siswa dapat membaca dengan cepat, karena kemampuan membaca dapat menjadi kunci keberhasilan belajar siswa. Berdasarkan realitas penggunaan metode kubaca dilaksanakan oleh semua guru. Dengan metode ini anak diharapkan dapat memahami kata yang telah dipersiapkan oleh guru.

\section{METODE}

Pendekatan penelitian ini menggunakan pendekatan kualitatif dan jenis penelitian lapangan, karena penelitian bertujuan mengungkap, menganalisis dan mendeskripsikan langkahlangkahpenggunaan metode Kubaca yang dapat meningkatkan kemampuan memahami huruf pada anak usia dini di Raudhatul Athfal Perwanida 19 Bangsalsari (Bogdan dan Taylor.1998:54).

Teknik pengumpulan data yang digunakan meliputi wawancara, observasi, dan dokumenter. Analisis data kualitatif dilakukansejak observasi awal, terjun ke lapangan (RA Perwanida 19), pengumpulan data hingga penarikan kesimpulan. Tahapan analisis data yang dipilih adalah Teknik analisis data kualitatif model interaktif Miles, Huberman, dan Saldana. Komponen dalam analysis interaktif ini terdiri atas koleksi data (data collection), kondensasi data (data condensation), penyajian data (data display), dan penarikan kesimpulan (conclusions drawing). Keabsahan data dilakukan dengan cara mencermati data yang diperoleh dari beberapa sudut pandang yang dikenal dengan triangulasi. Dari berbagai jenis triangulasi yang ada, yaitu triangulasi sumber, triangulasi pengamat (export judgement) triangulasi teori dan triangulasi metode, penelitian ini menggunakah triangulasi sumber dan metode (Miles, Huberman, dan Saldana. 2002:18).

\section{HASIL DAN PEMBAHASAN}

\section{Metode Kubaca Dapat Meningkatkan Kemampuan Mengenal Kata}

Metode kubaca dapat meningkatkan kemampuan mengenal kata. Hal ini sesuai dengan temuan penelitian bahwa penggunaan metode "kubaca" dapat meningkatan kemampuan mengenal kata di RA Perwanida 19 sangat efektif dalam pembelajaran. Yang berjudul penggunaan metode "kubaca" dapat meningkatan kemampuan mengenal kata di RA Perwanida 19. Dalam penelitian tersebut diungkapkan bahwa penggunaan metode "kubaca" dapat meningkatan kemampuan mengenal kata di RA Perwanida 19 sangat efektif dalam pembelajaran. Hal ini dapat memberikan pengetahuan pada diri anak untuk mengenal kata secara langsung. Hal ini dapat di lihat dari siswa memahami huruf yang tanyakan guru pada mereka, mereka menjawab dengan benar kata-kata yang ditanyakan. Bahkan ada siswa yang mampu dan lancar membaca. Hal ini menjadi kunci pengetahuan siswa pada setiap pelajaran yang diberikan sehingga dapat dieksplorasi dengan 
mudah. Sehingga siswa dapat menerapkan pengetahuannya dan memperkuat ingatan tentang pengetahuan yang dipelajari.

Hasil temuan di RA Perwanida 19 bahwa Karena sulitnya mengajari anak-anak usia dini, maka dibutuhkan ketelatenan pada setiap guru, perlu ada kemudahan dalam mengajar, sehingga setiap guru dituntut untuk memberikan pelajaran dengan metode yang berbeda beda salah satunya dengan metode kubaca, dengan menggunakan metode kubaca guru dapat lebih mudah menyampaikan pelajaran kepada anak karena dengan mengenal kata dan huruf diharapkan dapat membaca dengan lancar. Mulai metode ini digunakan banyak dukungan dari wali murid karena anaknya sudah dapat membaca abjad dan tulisan, sehingga guru makin gencar menggunakan metode ini disekolah.

Adapun pelaksanaannya tergantung dari kesiapan dan materi yang diajarkan, jika materi tersebut menyebutkan untuk membaca, maka para guru dengan sigap menggunakan metode kubaca yang telah disiapkan. Dengan langkah bermacam-macam, mulai dari sorokan, membaca bersamasama, atau mengikuti apa yang diucapkan guru. Mereka antusias ingin memahami huruf dengan metode kubaca.

Hal ini sesuai dengan penelitian terdahulu yang dilakukan oleh sitti pratiwi yang berjudul implementasi pembelajaran dengan metode membaca cepat kubaca untuk meningkatkan kemampuan membaca awal, bahwa hasil implementasi melalui metode kubaca dapat mempercepat siswa dapat membaca. Hal ini sesuai temuan penelitian terdahulu yang dilakukan oleh Ratna Juwita (2015: 12) dengan judul penelitian berjudul Penggunaan Teori "Kubaca" Terhadap Peningkatan Kemampuan Membaca siswa, dalam penelitian tersebut diungkapkan bahwa penggunaan teori "kubaca" terhadap peningkatan kemampuan membaca siswa hasilnya siswa ratarata sudah mampu membaca dengan kriteria penilaian.

Temuan penelitian ini sesuai dengan berbagai kelebihan yang dimiliki kubaca yaitu Menurut Sudrajat (2012: 74) Pembelajaran membaca merupakan suatu proses pembelajaran yang menitikberatkan pada penguasaan teks atau pemahaman teks yang dibaca serta kemampuan siswa dalam menjawab beberapa pertanyaan yang diberikan oleh guru. Metode Kubaca merupakan suatu metode membaca yang ditujukan untuk kepentingan studi, namun juga dapat diterapkan untuk kepentingan metode pengajaran membaca di sekolah. Demikian pula menurut Eva Nur Rachmah Pratama Sanjaya (2015:15) kelebihan metode pembelajaran kubaca : Siswa diarahkan untuk terbiasa berpikir terhadap bahan bacaan sehingga siswa menjadi lebih aktif dan terlatih untuk bisa membuat pertanyaan. Siswa berusaha untuk memikirkan jawaban-jawaban dari pertanyaan yang mendalami isi bacaan atau teks tersebut. Siswa dapat bekerjasama dalam kelompoknya untuk saling bertukar pendapat dalam memahami konsep materi yang disajikan dalam uraian teks. 


\section{Langkah-Langkah Penerapan Metode Kubaca untuk Meningkatkan Kemampuan Mengenal}

\section{Kata Anak Usia Dini}

Metode Kubaca terdiri atas lima langkah yakni survey yakni teknik untuk mengenal bahan sebelum membaca secara lengkap untuk mengenal organisasi dan ikhtisar umum, question yakni mengajukan pertanyaan tentang isi bacaan, read yakni membaca keseluruhan bahan bacaan, recite yaitu Setiap selesai membaca suatu subjudul, berhentilah sejenak untuk menjawab pertanyaan atau menyebutkan hal-hal penting dari bacaan tersebut dan review yakni Setelah membaca seluruh bacaan, ulangi untuk menelusuri kembali.

Langkah-langkah yang digunakan dalam menerapkan metode kubaca tidak lepas dari perencanaan, pelaksanaan dan evaluasi. Dalam perencanaan guru menyiapkan kartu sesuai dengan kata yang sering ditemui dan mudah diingat. Hal ini dapat memberikan kemudahan untuk mengingat pada diri anak untuk mengenal kata secara langsung. Hasil temuan di RA Perwanida 19 bahwa guru menyiapkan terlebih dahulu yang diperlukan dalam menggunakan metode ini, biasanya metode ini menggunakan kartu yang bertuliskan kata-kata yang sering kita jumpai, guru mempersiapkan kartu yang dibutuhkan tadi, agar nantinya siswa senang dengan kreatifitasi dan tulisan pada kartu kubaca.

Setelah persiapan yang dilakukan selesai, selanjutnya tahap pelaksanaan yaitu menggunakan metode kubaca, yang mana metode ini dimulai dengan diawali guru mengacungkan salah satu kata kemudian beliau membaca tulisan tersebut, siswa kemudian disuruh menirukan bunyi yang dibacakan guru pada kartu kata tersebut, demikian seterusnya hingga siswa benar-benar mengenal kata dari kartu tersebut. Guru harus lebih aktif dalam mengikuti pembelajaran dengan metode ini.

Hasil temuan tentang langkah-langkah penerapan kubaca di RA Perwanida 19 bahwa dari siswa mengingat kata yang ditanyakan guru pada mereka, mereka berusaha menjawab dengan mengingat kata yang telah disebutkan guru tadi. Sehingga secara tidak langsung siswa mengingat kata-kata tersebut. Dengan demikian siswa dapat mengasah ingatannya dari apa yang mereka lihat sehingga menambah pengetahuannya dalam mengenal kata.

Hal ini sesuai dengan penelitian terdahulu yang dilakukan oleh sitti pratiwi yang berjudul implementasi pembelajaran dengan metode membaca cepat kubaca untuk meningkatkan kemampuan membaca awal, bahwa hasil implementasi melalui metode kubaca dapat mempercepat siswa dapat membaca. Demikian pula dalam penelitian terdahulu yang dilakukan oleh Ratna Juwita (2015: 12) dengan judul penelitian berjudul Penggunaan Teori "Kubaca" Terhadap Peningkatan Kemampuan Membaca siswa, dengan hasil penelitiannya yaitu penggunaan teori "kubaca" terhadap peningkatan kemampuan membaca siswa hasilnya siswa rata-rata sudah mampu membaca dengan kriteria penilaian. 
Menurut Sitti Pratiwi dan Umi Hany Aprilia (2017: 46) "Pelaksanaan metode ini adalah dengan mengenalkan dengan lima kata-kata yang sudah akrab digunakan anak-anak. Setelah itu anak-anak diminta untuk menghafal dan menyusun dengan kalimat yang berbeda walaupun katakatanya sama". Hal senada juga disampaikan Febrilyan Sakuntala Dewi (2014: 89) penelitian terdahulu yang menyatakan bahwa "pembelajaran ini mencakup aspek hafalan membaca, ketepatan membaca, dan teknik".

\section{KESIMPULAN DAN SARAN}

Penggunaan metode kubaca dapat meningkatan kemampuan mengenal kata di RA Perwanida 19 dalam pembelajaran. Hal ini dapat di lihat dari kondisi siswa. Mereka dapat memahami huruf yang ditanyakan guru, mereka dapat menjawab dengan benar kata-kata yang ditanyakan. Bahkan ada siswa yang mampu dan lancar membaca. Langkah-langkah penggunaan metode kubaca ini sebagai berikut: (1) Guru pertama-tama menyiapkan aneka ragam atau macam kata-kata yang akan disampaikan kepada siswa, lalu mengacungkan kata-kata yang telah disusun secara rapi; (2) Guru membacakan kartu-kartu tersebut secara nyaring, sehingga anak dapat mendengar dengan jelas bunyi dari bacaan tersebut dan secara tidak langsung siswa dapat mengingat kata atau huruf yang ditunjukkan oleh guru; dan (3) Guru membacakan kartu kata-kata dengan keras atau nyaring dan mengulang-ulangnya sehingga siswa dapat lebih mudah mengingat kata yang ditampilkan.

\section{DAFTAR PUSTAKA}

Bogdan dan Taylor. 1998. Metodologi Penelitian Pendidikan. Bandung: Pustaka Setia.

Dalman. 2017. Keterampilan membaca. Jakarta: Raja Grafindo Persada.

Sajaya, E.N.R.P. 2015.Studi perbedaan kemampuan membaca permulaan pada anak yang mendapatkan pembelajaran dengan menggunakan metode kubaca dan metode membaca sebagai sarana kognitif anak di TK. Surabaya: Fakultas Psikologi Universitas 45.

Isjoni. 2017. Model Pembelajaran Anak usia Dini.Bandung : Alfabeta.

Kemendikbud. 2014. Peraturan Menteri Pendidikan Dan Kebudayaan Republik Indonesia Nomor 146 Tahun 2014 Tentang Kurikulum 2013 Pendidikan Anak Usia Dini. Jakarta: Ditjen Kemendiknas.

Rizka Rojiyatul Azizah dan Sulthoni. 2017. Pengaruh Metode "Kubaca" Dengan Gambar Terhadap Peningkatkan Kemampuan Membaca Permulaan Anak Tunarungu Kelas I SDLB. Malang: UNM.

Pratiwi, S dan Eprilia, U.H. 2017. implementasi pembelajaran dengan metode kubaca untuk meningkatkan kemampuan membaca awal, Surakarta: UNS.

Ratna Juwita. Penggunaan Teori "Kubaca” Terhadap Peningkatan Kemampuan Membaca siswa di SD Negeri Bentangan Klaten Tahun Pelajaran 2014/2015 Skripsi UNMUH Surakarta.

Sudrajat. 2012. Metode Membaca untuk anak, Bandung: Pustaka Setia. 
Dewi, F.S. 2014. penggunaan metode kucubaca dan demonstrasi pada siswa kelas I SD Negeri Baban Sumenep Skripsi UNMUH Malang. 